Jurnal Konstruksi Hukum | ISSN: XXXX | E-ISSN: XXXX Vol. 1, No. 2, Oktober 2020, Hal. 243-250| Available online at https://www.ejournal.warmadewa.ac.id/index.php/jukonhum DOI: https://doi.org/10.22225/jkh.1.2.2595.243-250

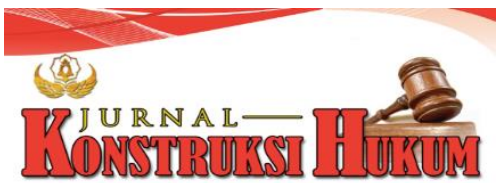

\title{
PERTIMBANGAN HUKUM TERHADAP PUTUSAN LEPAS DARI SEGALA TUNTUTAN HUKUM (ONTSLAG VAN RECHTSVERVOLGING)
}

\author{
Anak Agung Gede Wiweka Narendra, I Gusti Bagus Suryawan, I Made Minggu Widyantara \\ Fakultas Hukum Universitas Warmadewa, Denpasar-Bali, Indonesia
}

\begin{abstract}
Abstrak
Tingkat pengetahuan dan pemahaman masyarakat khususnya aparat penegak hukum sebagi pihak yang menjalankan peraturan perundang-undangan sering menyebabkan terjadinya kekeliruan dalam menafsirkan tindak pidana penipuan tersebut. Bukti menunjukkan bahwa masyarakat atau aparat penegak hukum yang menjalankan tugas apa bila suatu hubungan hukum yang dilakukan seseorang dengan orang lain yang semula sangat bersifat keperdataan (individual contract), seringkali dapat berkembang menjadi problem yang kompleks karena mengandung aspek yuridis lain, misalnya dimensi kepidanaan. Penelitian ini bertujuan untuk mengetahui pertimbangan hakim dalam memberikan putusan lepas dari segala tuntutan hukum sebagaimana hukum yang berlaku serta upaya hukum yang dapat dilakukan atas putusan lepas dari segala tuntutan hukum atas perkara pidana. Penelitian ini menggunakan metode penelitian normatif yang sifatnya deskriptif. Sumber data yang digunakan yaitu bahan hukum sekunder sebagai dasar penelitian. Pengumpulan data dalam penelitian ini adalah studi kepustakaan (studi dokumen) yaitu pengumpulan bahan hukum dengan melalui bahan hukum tertulis dengan Teknik analisis analisis eduksi (deduksi) yaitu menarik kesimpulan dari hal yang bersifat umum terhadap permasalahan konkret yang dihadapi. Berdasarkan analissi data adapun hasil dalam penelitian ini adalah dasar pertimbangan hakim memberikan putusan lepas dari segala tuntutan hukum ialah bilamana yang didakwakan bisa dibuktikan secara sah dan meyakinkan dengan dikuatkan alat bukti sehingga didapat keyakinan hakim namun tidak termasuk kedalam tindak pidana sebagaimana termuat pada pasal 191 ayat (2) KUHAP yang mengharuskan dinyatakan dilepaskan dari segala tuntutan hukim.
\end{abstract}

Kata Kunci: Pertimbangan Hukum; Tuntutan Hukum; Putusan Hukum.

\begin{abstract}
Absract
People's knowledge and understanding of the community, especially law enforcement officials as the one who implement the laws and regulations, often causes mistakes in interpreting the criminal act of fraud. Evidence shows that the public or law enforcement officials who carry out their duties if a legal relationship is carried out by someone with another person, which was originally very civil in nature (individual contract), can often develop into a complex problem because it contains other juridical aspects, for example the dimension of the crime. This study aims to determine the judge's consideration in giving a decision that is free from all lawsuits as well as the legal remedies that can be made on a decision that is free from all lawsuits in criminal cases. This study uses a descriptive normative research method. Sources of data used are secondary legal materials as the basis for research. Data collection in this study was carried out by literature study (document study), namely the collection of legal materials through written legal materials with deduction analysis techniques. Deductive analysis is drawing conclusions from general matters regarding the concrete problems faced. After the analyzing the data, the results showed that the basis for the judge's consideration of giving a verdict that is free from all lawsuits is if the accused can be proven legally and convincingly and strengthened by evidence so that the judge's conviction is obtained but it is not included in a criminal act as contained in Article 191 point (2) KUHAP which requires that it be declared to be released from all legal demands.
\end{abstract}

Keywords: Legal considerations; Lawsuits; Legal verdict. 


\section{PENDAHULUAN}

Pengadilan adalah suatu lembaga peradilan atau badan penegak hukum yang menjadi tumpuan harapan untuk mencari keadilan melalui penyelesaian suatu perkara hukum acara pidana yang bertujuan untuk mendapatkan atau mendekati kebenaran materiil (Boyoh, 2015). Hal ini berguna menemukan terdakwa untuk dilakukan upaya paksa dan putusan dari pengadilan guna menentukan subyek hukum yang dapat dipersalahkan dimana dalam hal ini hakim sangat berperan dalam memutus suatu perkara termasuk memberikan putusan lepas dari segala tuntutan hukum yang masih memerlukan kecermatan agar sesuai sebagaimana diatur dan ditentukan dalam peraturan perundang-undangan. Sebagai penegak hukum, hakim mempunyai tugas dibidang yudisial, yaitu menerima, memeriksa, memutuskan dan menyelesaikan setiap perkara yang diajukan kepadanya (Nurhafifah \& Rahmiati, 2015).

Berdasarkan penelitian dari yurisprudensi hakim sebagaimana menjadi pembahasan dalam penelitian ini, yakni Putusan Mahkamah Agung RI Nomor: 1/Pid.B/2016/PN.Amp tanggal 26 Mei 2016 atas nama terdakwa I Made Suta bahwa dasar pertimbangan hakim memberikan putusan lepas dari segala tuntutan hukum adalah bilamana perbuatan terdakwa dapat dibuktikan namun perbuatan tersebut tidak tergolong suatu tindak pidana. Sebagaimana termuat pada pasal 191 ayat (2) KUHAP terdakwa harus dinyatakan dilepaskan dari segala tuntutan hukum. Konstitusi kedaulatan hukum yang pada pokoknya menganut prinsip supremasi hukum. Artinya segala aspek kehidupan berbangsa dan bernegara harus merujuk pada hukum yang berlaku (Pattiruhu et al., 2019). Kesesuaian putusan hakim lepas dari segala tuntutan hukum jika dilihat dari perspektif hukum yang berlaku sudah akurat karena setelah melalui persidangan yang didasarkan alat bukti sehingga didapat keyakinan hakim yakni perbuatan terdakwa benar telah terbukti tidak tergolong suatu tindak pidana karena masih ada sengketa hak yang harus diselesaikan melalui hakim Perdata. Penelitian ini bertujuan untuk mengetahui pertimbangan hakim dalam memberikan putusan lepas dari segala tuntutan hukum sebagaimana hukum yang berlaku serta upaya hukum yang dapat dilakukan atas putusan lepas dari segala tuntutan hukum atas perkara pidana

\section{METODOLOGI PENELITIAN}

Penelitian ini menggunakan penelitian hukum normatif yang bersifat preskriptif, dengan menggunakan pendekatan kasus. Jenis bahan hukum yang digunakan adalah sumber bahan hukum primer dan bahan hukum sekunder. Teknik pengumpulan bahan hukum yang digunakan adalah studi dokumen (studi kepustakaan). Teknis analisis bahan hukum adalah dengan menggunakan analisis deduksiyaitu menarik kesimpulan dari hal yang bersifat umum terhadap permasalahan konkret yang dihadapi (Poerbaning et al., 2013).

\section{HASIL PENELITIAN DAN PEMBAHASAN Dasar Pertimbangan Hakim dalam Menjatuhkan Putusan Lepas dari Segala Tuntutan Hukum}

Suatu proses peradilan berakhir dengan putusan akhir atau vonis yang berarti hasil akhir pemeriksaan perkara di sidang pengadilan (Bambang Sunggono, 2011). Putusan pengadilan yakni pernyataan hakim yang terucap saat sidang pengadilan terbuka. KUHAP mengatur 3 (tiga) jenis putusan hakim pidana sebagaimana termuat pada pasal 191 ayat (1), (2) serta 193 ayat (1) KUHAP adalah sebagai berikut: 1. Putusan Bebas atau Vrijspraak

Sebagaimana termuat pada pasal 191 ayat (1) KUHAP yang mengatur tentang putusan bebas berbunyi Jika pengadilan berpendapat bahwa saat persidangan kesalahan terdakwa tidak bisa dibuktikan secara sah dan meyakinkan, jadi terdakwa diputus bebas. Hakim menjatuhkan putusan bebas bilamana melalui pemeriksaan di persidangan ditemukan hal berikut.

a) Pembuktian di persidangan, dinilai tidak cukup membuktikan kesalahan terdakwa yang tanpa disertai keyakinan hakim sehingga tidak memenuhi asas pembuktian menurut undang-undang secara negatif.

b) Tidak terpenuhinya batas minimum pembuktian saat dilakukannya pembuktian di persidangan sebagaimana bertentangan dengan asas pasal 183 dikaitkan Pasal 192 ayat (1) KUHAP bahwa pada umumnya putusan bebas berdasarkan atas penilaian dan pendapat dari hakim: 
(1) Kesalahan yang didakwakan sama sekali tidak terbukti secara sah dan meyakinkan, seluruh alat bukti yang diserahkan ke persidangan tidak dapat membuktikan kesalahan terdakwa

(2) Penilaian hakim saat pembuktian terhadap kesalahan terdakwa tidak dapat mencapai batas minimum pembuktian

(3) Secara formal berdasarkan atas penilaian bahwa kesalahan yang terbukti tersebut tidak diikuti oleh keyakinan hakim yang berakibat terhadap lumpuhnya nilai pembuktian yang cukup.

c) Putusan Pemidanaan

Sebagaimana termuat Pasal 193 ayat (1) KUHAP yang mengatur tentang bentuk putusan pemidanaan mererangkan jikalau Pengadilan berpendapat bahwa terdakwa bersalah melakukan tindak pidana, maka pengadilan menjatuhkan hukuman pidana

d) Putusan Lepas Dari Segala Tuntutan Hukum

Sebagaimana termuat pada pasal 191 ayat (2) KUHAP yang mengatur tentang putusan lepas dari segala tuntutan hukum menerangkan jikalau pengadilan berpendapat perbuatan terdakwa bisa dibuktikan tetapi bukan tergolong tindak pidana, hakim haruslah memberikan putusan lepas dari segala tuntutan hukum. Adapun sebab-sebab terdakwa diputus lepas dari segala tuntutan hukum sebagai berikut:

1) Diantara hukum pidana yang didakwakan terhadap terdakwa tidak termasuk tindak pidana; semisal perbuatan yang dituntut sebagai tindak pidana namun didapati fakta bahwa perbuatan tersebut bukan tergolong hukum pidana namun tergolong hukum perdata

2) Adanya keadaan istimewa yang membuat terdakwa tidak dapat dihukum sebagaimana termuat pada pasal 44, 48, 49, 50, 51 KUHP. (Silalahi, 2015). Terdapat tujuh keadaan istimewa yang membuat si pembuat tidak bisa dipidana sebagaimana ditentukan Undang-Undang Bab III KUHAP:

a) Sebagaimana termuat pada pasal 44 ayat (1) menerangkan adanya ketidakmampuan bertanggung jawab si pembuat pidana pidana atau ontoerekeningsvatbaarheid

b) Sebagaimana termuat pada pasal 48 menerangkan danya daya paksa atau overmacht

c) Sebagaimana termuat pada pasal 49 ayat (1) menerangkan adanya pembelaan terpaksa/noodweer

d) Sebagaimana termuat pada pasal 49 ayat (2) menerangkan adanya pembelaan terpaksa yang melampaui batas atau noodwerexes

e) Sebagaimana termuat pada pasal 50 menerangkan karena sebab menjalankan perintah undangundang

f) Sebagaimana termuat pada pasal 51 ayat (1) menerangkan karena melaksanakan perintah jabatan yang sah

g) Sebagaimana termuat pada pasal 51 ayat (2) menerangkan karena sebab menjalankan perintah jabatan yang tidak sah dengan itikad baik

Doktrin hukum pidana menyatakan ada 7 hal yang mengakibatkan pelaku pidana tidak bisa dipidana, dibedakan atas 2 bagian kemudian dikelompokan sebagai berikut:

1) Berdasarkan atas Pemaaf bersifat subyektif dan melekat pada diri orangnya, khususnya menyangkut sikap bathin sebelum dan atau pada saat akan berbuat.

2) Sebagaimana diatur menurut doktrin hukum pidana, dasar pemaaf yakni:

a) Sebagaimana termuat pada pasal 44 ayat (1) tentang Ketidakmampuan bertanggung jawab menerangkan melakukan perbuatan yang tidak dapat dipertanggungjawabkan kepadanya karena terdapat kekurangan dalam hal ini cacat jiwa saat pertumbuhan atau mempunyai gangguan yang diakibatkan oleh penyakit tidak bisa dipidana

b) Sebagaimana termuat pada pasal 49 ayat (2) tentang Pembelaan terpaksa yang melampaui batas menerangkan pembelaan terpaksa yang melampaui batas yang karena kekhawatiran jiwa yang hebat akibat adanya serangan dan atau ancaman tidak bisa dipidana

c) Sebagaimana termuat pada pasal 51 ayat (2) tentang Hal menjalankan perintah jabatan yang tidak sah dengan itikad baik menerangkan Perintah jabatan yang diberi oleh pembesar yang 
tidak berhak, tidak membebaskan dari hukuman, terkecuali kejujuran pegawai yang dibawahnya mengira pembesar itu berhak akan memberi perintah itu.

3) Berdasarkan atas pembenar yang sifatnya obyektif dan melekat pada perbuatannya atau berkaitan dengan hal yang lain diluar dari pada batinnya sebagaimana diatur sesuai doktrin hukum pidana diartikan sebagai berikut:

a) Adanya daya paksa sebagaimana termuat pada pasal 48 menerangkan melakukan perbuatan karena pengaruh daya paksa tidak bisa dipidana

b) Adanya pembelaan terpaksa sebagaimana termuat pada pasal 49 ayat (1) menerangkan dengan terpaksa melakukan perbuatan sebagai pembelaan yang disebabkan adanya serangan/ancaman yang mengakibatkan adanya perlawanan yang bertentangan oleh hukum sebagaimana diatur yang menyangkut pribadi ataupun orang lain terkait kehormatan kesusilaan/harta benda tidak bisa dipidana

c) Karena menjalankan perintah undang-undang sebagaimana termuat pada Pasal 50 menerangkan, melakukan perbuatan untuk melaksanakan ketentuan undang-undang tidak dapat dipidana

d) Karena melakukan perintah jabatan yang sah sebagaimana termuat pada Pasal 51 ayat (1) menerangkan melakukan perbuatan untuk menjalankan perintah jabatan yang diberikan pembesar yang berhak

Pelaku tidak dipidana berdasarkan atas pemaaf yakni bahwa walaupun pelaku, perbuatannya terbukti melanggar dan atau melawan hukum namun dikarenakan hapusnya kesalahan maka perbuatannya tak bisa dipertanggungjawabkan pelaku, sehingga berdasarkan alasan tersebut di atas maka si pembuat dapat dimaafkan atas perbuatannya itu (Makanoneng, 2016). Kendatipun pada hakikatnya perbuatan pelaku dengan merujuk pada unsur tindak pidana dapat terpenuhi, namun demikian dikarenakan hapusnya sifat melawan hukum pada perbuatan tersebut sehingga apa yang dilakukan oleh si pembuat menjadi perbuatan yang benar. Berdasarkan atas pembenar tersebut maka si pembuatnya tidak dapat dipidana atas perbuatannya

\section{Upaya Hukum yang Dapat Dilakukan atas Putusan Lepas dari Segala Tuntutan Hukum}

Upaya hukum dimaksudkan sebagai perlindungan terhadap tindakan kesewenang-wenangan hakim atau pengadilan serta sebagai sarana revisi terhadap kesalahan instansi sebelumnya dan untuk kesatuan dalam peradilan. Keadilan sebagai eksistensi hukum dalam peradilan pidana merupakan elemen penting dalam kaitannya dengan HAM, karena bicara keadilan dalam sudut pandang HAM maka nilai HAM merupakan norma moral dan sarana bagi hukum untuk menciptakan cita-citanya melindungi semua umat manusia dari penyalahgunaan dan pemberlakuan kekuatan tirani di bidang hukum, ekonomi, sosial dan politik yang berlaku di tingkat nasional maupun internasional (Fauzi, 2014). Berkaitan dengan hal tersebut di atas upaya hukum terbagi atas 2 bagian yaitu:

1. Upaya hukum biasa

1) Verzet (Perlawanan) sebagaimana termuat pada pasal 214 ayat (4) KUHAP, Verset adalah perlawanan terdakwa terhadap putusan pengadilan diluar kehadiran terdakwa atau perlawanan penuntut umum berkaitan dengan tidak diterimanya tuntutan atas penetapan pengadilan atau, bukan wewenang pengadilan memeriksa perkara atau, bukan kompetensi pengadilan sebagaimana termuat pada pasal 149 \& 156 KUHAP;

2) Banding sebagaimana termuat pada pasal 67 KUHAP menerangkan hak memohon banding terkecuali terhadap putusan bebas atau lepas dari segala tuntutan hukum terkait tidak akuratnya penerapan hukum dan putusan pengadilan dalam acara cepat

3) Kasasi yakni hak terdakwa dan penuntut umum untuk meminta pembatalan putusan pengadilan negeri atau pengadilan tinggi karena

a) bukan merupakan kewenanganya/melewati batas kewenangan

b) melanggar hukum yang berlaku atau kesalahan di dalam penerapan hukum tersebut 
c) lalai terpenuhi sebagaimana syarat yang diwajibkan oleh peraturan perundang-undangan yang mengancam kelalaian tersebut sehingga dapat mengakibatkan dibatalkannya putusan 2. Upaya hukum luar biasa

1) Kasasi sebagaimana termuat pada pasal 259 ayat (1) KUHAP tentang Kasasi demi kepentingan hukum menerangkan terhadap seluruh putusan berkekuatan hukum tetap yang berasal dari pengadilan terkecuali dari Mahkamah Agung, dapat dimonkan kasasi.

2) Peninjauan Kembali sebagaimana termuat pada pasal 263 ayat (1) menerangkan terhadap seluruh putusan yang berkekuatan hukum tetap, terkecuali putusan bebas/ lepas dari segala tuntutan hukum dapat memohon peninjauan kembali kepada Mahkamah Agung.

Untuk dapat lebih dipahami terkait upaya hukum yang ditempuh terdakwa dan atau penuntut umum mengenai putusan pelepasan terdakwa dari segala tuntutan hukum, dapat diperhatikan yurisprudensi Hakim yang diambil sebagai salah satu contoh dalam penelitian ini sebagai berikut: Kutipan Putusan Mahkamah Agung RI No: 1/Pid.B/2016/PN.Amp tanggal 26 Mei 2016 atas nama terdakwa I Made Suta (terhadap diri Terdakwa tidak dilakukan penahanan):

1) Hasil pemeriksaan dipersidangan, maka selanjutnya sampailah pada pertimbangan yuridis Majelis Hakim tentang perbuatan terdakwa

2) Menimbang, bahwa untuk menyatakan seseorang dapat dipersalahkan melakukan suatu tindak pidana harus memenuhi seluruh unsur dakwaan secara sah dan meyakinkan bersalah mengacu pada pasal 183 KUHAP

3) Menimbang, bahwa Terdakwa diajukan ke persidangan oleh Penuntut Umum dengan dakwaan Pasal 372 KUHP juncto Pasal 64 ayat (1) KUHP yang mana unsur-unsurnya ialah:

Ad. 1 Unsur Barang Siapa

Menimbang bahwa dalam pemeriksaan persidangan berdasarkan pengamatan Majelis Hakim. Terdakwa adalah orang yang sehat jasmani dan rohani sehingga harus dipandang sebagai orang yang dapat mempertanggungjawabkan perbuatannya menurut hukum, demikian pula identitas Terdakwa telah bersesuaian dengan Surat dakwaan sehingga tidak terjadi error in persona maka unsur barang siapa telah terpenuhi.

Ad. 2 Unsur dengan Sengaja dan Melawan Hukum Memiliki Barang Sesuatu yang Seluruhnya atau Sebagian Milik Orang Lain

Menimbang, bahwa dalam persidangan keterangan Saksi korban Pande Ketut Kawi Aryawan yang bersesuaian dengan keterangan Perbekel Desa Nongan yaitu I Nengah Supartana dan didukung keterangan adik kandung Terdakwa yaitu Saksi I Komang Wita yang menyatakan bahwa Terdakwa I Made Suta adalah Penggarap di kebun milik Saksi korban dan keluarganya yang terletak di Dsn. Pande, Ds. Nongan, Kec. Rendang, Kab. Karangasem, dan telah dikuatkan dengan bukti fotocopy sertifikat tanah Nomor: 2230 atas nama pemegang hak I Made Ardika, I Komang Kayun, Pande Komang Swardika, Pande Ketut Kawi Aryawan, I Putu Kolem, I Made Suamba, I Made Agus Pande Asrama, Pande Made Sukarta bahwa berdasarkan uraian pertimbangan tersebut, menurut hemat maka unsur dengan sengaja dan melawan hukum memiliki barang sesuatu yang seluruhnya atau sebagian milik orang lain telah terpenuhi.

Ad. 3 Unsur yang Ada Dalam Kekuasaannya Bukan Karena Kejahatan

Menimbang bahwa berdasarkan keterangan saksi Pande Ketut Kawi Aryawan, I Putu Rimbawan, Ni Wayan Suryani Als Luh Cablek, I Komang Wita, I Nengah Supartana, I Putu Nata, dan I Komang Sudarka dan keterangan Terdakwa I Made Suta yang dikuatkan dengan barang bukti buah kelapa terungkap fakta bahwa I Made Suta merupakan seorang penggarap di kebun milik keluarga Pande Ketut Kawi Aryawan yang terletak di Dsn. Pande, Ds. Nongan, Kec. Rendang, Kab. Karangasem. Bahwa ayah Terdakwa yang bernama I Wayan Kontalan sejak dahulu bekerja di kebun milik keluarga Pande Ketut Kawi Aryawan tersebut, dan kemudian di teruskan oleh Terdakwa sebagai anaknya; Bahwa benar kebun tersebut adalah milik saksi dan keluarganya sesuai sertifikat hak milik No: 2230 yang dikeluarkan BPN pada tahun 2012 melalui program nasional 
atas nama I Made Ardika, I Komang Kayun, Pande Komang Swardika, Pande Ketut Kawi Aryawan, I Putu Kolem, I Made Suamba, I Made Agus Pande Asrama, Pande Made Sukarta; Bahwa biasanya saksi dan keluarganya menerima hasil kebun dari terdakwa sebanyak tiga ratus butir buah kelapa setiap tiga bulan sekali dan seribu kilogram buah salak setiap satu tahun sekali maka unsur yang ada dalam kekuasaannya bukan karena kejahatan telah terpenuhi.

Ad. 4 Unsur Antara Beberapa Perbuatan, Meskipun Masing-Masing Merupakan Kejahatan atau Pelanggaran, Ada Hubungan Sedemikian Rupa Sehingga Harus Dipandang Sebagai Perbuatan Berlanjut Menimbang, bahwa fakta yang berhasil diungkap dimuka persidangan, berdasarkan keterangan saksi-saksi bahwa sejak lama keluarga Pande Ketut Kawi Aryawan menerima hasil kebun dari Terdakwa sebanyak tiga ratus butir buah kelapa setiap tiga bulan sekali dan seribu kilogram buah salak setiap satu tahun sekali. Bahwa sejak terbitnya sertifikat hak milik Nomor 2230 yang dikeluarkan oleh Badan Pertanahan Nasional pada tahun 2012 melalui program nasional, terdakwa tidak pernah menyerahkan hasil panen kebun tersebut kepada Pande Ketut Kawi Aryawan maupun keluarganya hingga sekarang, sehingga Pande Ketut Kawi Aryawan dan keluarganya mengalami kerugian sebesar \pm Rp.10.000.000 (sepuluh juta rupiah). Menimbang, bahwa berdasarkan pengakuan Terdakwa bahwa hasil kebun tersebut tidak pernah Terdakwa setorkan karena terdakwa yang merasa memiliki kebun tersebut, dan uangnya dipergunakan untuk memenuhi kebutuhan hidupnya sehari-hari bahwa dengan demikian, Unsur Antara Beberapa Perbuatan, Meskipun Masing-Masing Merupakan Kejahatan atau Pelanggaran, Ada Hubungan Sedemikian Rupa Sehingga Harus Dipandang Sebagai Perbuatan Berlanjut telah terpenuhi.

Berdasarkan hasil keputusan tersebut, Jaksa Penuntut Umum menyatakan Banding dihadapan Panitera PN Amlapura pada tanggal 2 Juni 2016 dengan putusan perkara pidana yang dijatuhkan oleh Pengadilan Tinggi Denpasar Nomor: 24/PID/2016/PT.DPS tanggal 10 Agustus 2016 dengan rangkuman:

1) Menimbang bahwa terdakwa I Made Suta terbukti melakukan beberapa kejahatan/pelanggaran yang berkaitan sehingga harus dipandang sebagai perbuatan berlanjut, pada bulan Desember 2012 hingga bulan Agustus tahun 2015 atau setidak-tidaknya pada waktu lain tahun 2012 hingga tahun 2015 bertempat di Subak Abian Kebon, Ds. Nongan, Kec. Rendang, Kab. Karangasem atau ditempatkan diwilayah hukum PN Amlapura, dengan sengaja dan melawan hukum memiliki barang sesuatu yang seluruhnya atau sebagian kepunyaan orang lain, tetapi dalam kekuasaannya bukan karena kejahatan sebagaimana pasal 372 juncto pasal 64 ayat (1) KUHP

2) Menimbang bahwa pertimbangan Hakim di tingkat pertama tidak menyeluruh terkait bantahan terdakwa atas keterangan saksi korban

3) Menimbang, bahwa masih ada sengketa hak dalam perkara ini, disatu pihak saksi Pande Ketut Kawi Aryawan mengaku sebagai pemilik tanah sesuai sertifikat yang terbit tahun 2012 dipihak lain terdakwa mengaku tidak pernah menyerahkan hasil kepada siapapun tetap dinikmati sendiri.

4) Menimbang, bahwa harus ada putusan Hakim perdata lebih dahulu untuk menentukan pembuktian yuridis terhadap sertifikat hak milik tersebut.

5) Menimbang, bahwa perbuatan terdakwa dinyatakan terbukti namun tidak tergolong sebagai tindak pidana haruslah dilepaskan dari segala tuntutan hukum sebagaimana termuat pada pasal 191 ayat (2) KUHAP

6) Menimbang, bahwa berdasarkan pertimbangan putusan PN Amlapura tanggal 26 Mei 2016 Nomor: 1/Pid.B/2016/PN.Amp harus dibatalkan, Pengadilan Tinggi akan mengadili sendiri perkara ini dengan putusan menerima permohonan Banding dari Jaksa Penuntut Umum serta membatalkan Putusan PN Amlapura yang dimintakan Banding tersebut.

a) Mengadili Sendiri:

b) Perbuatan terdakwa terbukti namun bukan merupakan tindak pidana

c) Melepaskan terdakwa dari segala tuntutan hukum 
d) Memulihkan hak terdakwa kemampuan, kedudukan, harkat dan martabat

e) Menetapkan barang bukti berupa: 1 (satu) buah fotocopy sertifikat tanah dengan nomor 2230 atas nama pemegang hak I Made Ardika, I Komang Kayun, Pande Komang Swardika, Pande Ketut Kawi Aryawan, I Putu Kolem, I Made Suamba, I Made Agus Pande Asrama, Pande Made Sukarta

Atas putusan tersebut dimohonan Kasasi kembali tanggal 5 September 2016 dengan permohonan Kasasi Nomor 2/Akta.Pid/2016/PN.Amp yang diputus oleh Mahkamah Agung RI Nomor 1261 K/PID/2017 tanggal 14 Februari 2017 menolak permohonan kasasi dari pemohon kasasi/jaksa penuntu umum.

Dasar putusan dapat dirangkum sebagai berikut:

Bahwa alasan permohonan Kasasi/Jaksa Penuntut Umum tidak dapat dibenarkan, oleh karena Judex Facti tidak salah menerapkan hukum karena hal yang relevan sudah dipertimbangkan secara yuridis. Perbuatan terdakwa tidak menyetorkan hasil kebun kepada Pande Ketut Kawi Aryawan maupun keluarganya, karena terdakwa merasa memiliki kebun berdasarkan terbitnya Sertifikat Hak Milik Nomor 2230 Tahun 2012 sehingga dalam perkara a quo ada sengketa kepemilikan yang penyelesaiannya harus melalui peradilan perdata.

a) Bahwa lagi pula alasan permohonan kasasi tersebut mengenai penilaian hasil pembuktian yang bersifat penghargaan terkait kenyataan, alasan semacam itu tidak dapat dipertimbangkan dalam pemeriksaan pada tingkat diterapkan atau tidaknya suatu peraturan hukum sebagaimana mestinya.

b) Menimbang bahwa berdasarkan pertimbangan tersebut, lagi pula ternyata putusan Judex Facti dalam perkara ini tidak bertentangan dengan hukum dan/atau undang-undang, maka permohonan Kasasi harus ditolak.

c) Bahwa karena permohonan Kasasi ditolak dan terdakwa dilepaskan dari segala tuntutan hukum, maka biaya perkara dibebankan kepada Negara.

\section{SIMPULAN DAN SARAN}

\section{Simpulan}

Dari hasil analisis data dapat disimpulkn bahwa:

1. Pada saat hakim hendak memutus perkara dalam bentuk putusan lepas dari segala tuntutan hukum dimana hakim dituntut agar senantiasa memutus berlandaskan hal-hal yang ditetapkan dan diatur undang-undang serta diperkuat oleh keyakinan yang ada pada diri hakim. Dalam hal penelitian pada kasus ini, diperoleh perbedaan putusan Hakim tingkat pertama dengan Putusan Hakim tingkat Pengadilan Tinggi, yang mana pada pengadilan pertama Hakim memberikan pidana penjara tiga bulan karena bersalah melakukan tindak pidana penggelapan yang dilakukan secara berlanjut sebagaimana sesuai dengan Pasal 372 juncto Pasal 64 ayat (1) KUHP sebagaimana dipersangkakan kepada terdakwa meskipun tidak dilakukan penahanan. Sedangkan pada tingkat banding di Pengadilan Tinggi, Hakim memberikan putusan lepas dari segala tuntuan hukum kepada terdakwa karena perkara tersebut dinyatakan oleh Hakim bukan merupakan tindak pidana karena masih ada sengketa hak yang harus diselesaikan melaui putusan Hakim Perdata. Perbedaan pandangan Hakim harusnya bisa dikurangi

2. Berdasarkan kesesuaian hakim memberikan putusan lepas dari segala tuntutan hukum jika dikaitkan dengan hukum yang berlaku sudah akurat karena setelah melalui persidangan yang didasarkan alat bukti sehingga didapat keyakinan hakim yakni perbuatan terdakwa benar telah terbukti namun perbuatan tersebut bukan merupakan suatu tindak pidana karena masih ada sengketa hak yang harus diselesaikan melalui hakim Perdata.

\section{Saran}

Berdasarkan hasil penelitian ada beberapa saran yang sekiranya dapat bermanfaat bagi penegakan hukum di waktu yang akan datang antara lain sebagai berikut: 
1) Hakim disaat hendak memutus perkara bisa menimbang secara akurat sebagaimana fakta dan buktibukti di persidangan demi timbulnya keadilan bagi seluruh pihak terkait.

2) Bilamana perkara diputus dengan putusan lepas dari segala tuntutan hukum, yang menjadi penekanan bahwa Hakim harus didasarkan pada apa yang menjadi aturan dalam undang-undang sebagaimana ditetapkan dengan turut didukung oleh keyakinan hakim.

\section{DAFTAR PUSTAKA}

Bambang Sunggono. (2011). Metedologi Penelitian Hukum,.

Boyoh, M. (2015). Independensi Hakim dalam Memutus Perkara Pidana Berdasarkan Kebenaran Materil. Lex Crimen, 4(4), 115-122.

Fauzi, A. (2014). Analisis Yuridis terhadap Upaya Hukum Luar Biasa Peninjauan Kembali (Pk) oleh Jaksa dalam Sistem Hukum Acara Pidana Indonesia. Jurnal Ilти Hukum, 4(2), 138-160.

Makanoneng, D. (2016). Catatan Kejiwaan Sebagai Alasan Penghapus Pidana. Lex Crimen, 5(4), 131-137.

Nurhafifah, \& Rahmiati. (2015). Pertimbangan Hakim dalam Penjatuhan Pidana Terkait hal yang Memberatkan dan Meringankan Putusan. Kanun: Jurnal Ilmu Hukum, 17(66), 341-362.

Pattiruhu, F., Saul, S., \& Wewo, J. A. (2019). Kajian Yurudis terhadap Putusan Sela nomor: 39/PID.SUSTPK/2018/PN.KPG pada Pengadialn Tindak Pidana Korupsi di Pengadilan Negeri Kupang. Jurnal Spektrum Hukum, 16(2), 28-39.

Poerbaning, V., Gilang, A. Y., Ramadhania, \& Fatimah, M. U. (2013). Tinjauan Yuridis Pengajuan Kasasi oleh Penuntut Umum terhadap Putusan lepas dari Segala Tuntutan Hukum. Jurnal Verstek, 1(3), 136-146.

Silalahi, V. P. (2015). Tinjauan Pengajuan Kasasi Penuntut Umum terhadap Putusan Lepas dari Segala Tuntutan Hukum Pengadilan Tinggi Sumatera Utara dalam Perkara Kehutanan. Gema, 27(50), 1883-1892. 